\title{
Ethnoveterinary knowledge of the inhabitants of Marajó Island, Eastern Amazonia, Brazil
}

\author{
Maria Vivina Barros MONTEIROํ, Claudia Maria Leal BEVILAQUA², Maria das Dores Correia PALHA², \\ Roberta Rocha BRAGA ${ }^{4}$, Katiane SCHWANKE ${ }^{5}$, Silvane Tavares RODRIGUES ${ }^{6}$, Osmar Alves LAMEIRA ${ }^{7}$
}

\begin{abstract}
There have been ethnoveterinary reports from around the world investigating plant usage in therapeutic protocols; however, there is no information regarding the ethnoveterinary practices in Brazilian Amazonia. The objective of this work was to register and document the ethnoveterinary knowledge of the inhabitants of the Island of Marajó, eastern Amazonia, Brazil. In the study, interviews were conducted with 50 individuals, with the application of semi-structured questionnaires that were quantitatively analyzed using descriptive statistic methods of frequency distribution. Use-value was calculated to determine the most important species. Samples of plants that were reported to have medicinal value were collected and identified by botanical classification. Fifty plants, distributed among 48 genera and 34 families, were indicated for 21 different medicinal uses. The family Asteraceae had the largest number of reported species; Carapa guianensis Aubl., Copaifera martii Hayne, Crescentia cujete L., Caesalpinia ferrea Mart., Chenopodium ambrosioides L., Jatropha curcas L. and Momordica charantia L. were species with highest use- value. The plant parts that were more commonly utilized for the preparation of ethnoveterinary medicines were the leaves $(56 \%)$, bark $(18 \%)$, roots (14\%), seeds $(14 \%)$ and fruit $(8 \%)$. With regard to usage, tea was reported as a usage method by $56 \%$ of the informants; most preparations $(90.9 \%)$ utilized only a single plant. In addition to medicinal plants, informants reported using products of animal and mineral origin. The present study contributed to the construction of an inventory of Marajó Island's ethnoveterinary plants, which might be the basis for future scientific validation studies.

Keywords: Brazilian Amazonia, ethnobotany, folk veterinary medicine, medicinal plants
\end{abstract}

\section{Conhecimento etnoveterinário dos habitantes da Ilha de Marajó, Amazônia Oriental, Brasil}

\begin{abstract}
RESUMO
Em várias partes do mundo existem relatos etnoveterinários sobre a utilização de plantas em protocolos terapêuticos, entretanto não existem informações disponíveis sobre a etnoveterinária praticada na Amazônia brasileira. Desta forma, objetivou-se documentar o conhecimento etnoveterinário de habitantes da Ilha do Marajó, Amazônia Oriental. Foram realizadas 50 entrevistas individuais com aplicação de questionários semi-estruturados que foram analisados quantitativamente através de estatística descritiva utilizando freqüência de distribuição. $\mathrm{O}$ valor de uso foi calculado para determinar as espécies mais importantes. Amostras de plantas com relatos de uso medicinal foram coletadas e identificadas botanicamente. Cinqüenta plantas, distribuídas em 48 gêneros e 34 famílias, foram indicadas para 21 diferentes usos medicinais. A família Asteraceae foi a que teve maior número de espécies citadas e Carapa guianensis Aubl, Crescentia cujete L., Copaifera martii Hayne, Caesalpinia ferrea Mart., Chenopodium ambrosioides L., Jatropha curcas L. e Momordica charantia L. foram as espécies com maiores valor de uso. As partes das plantas mais utilizadas para preparo dos medicamentos etnoveterinários foram folhas (56\%), cascas (18\%), raizes (14\%), sementes (14\%) e frutos (8\%). Quanto à forma de uso o chá foi citado por 56\% dos entrevistados e a maioria das preparaçóes $(90,9 \%)$ utiliza uma só planta. Além das plantas medicinais, os entrevistados relataram o uso de produtos de origem animal e mineral. Esse trabalho contribui para realização de um inventário das plantas utilizadas na etnoveterinária marajoara que pode servir de base de dados para futuros estudos de validação científica.
\end{abstract}

PALAVRAS-CHAVE: Amazônia brasileira, etnobotânica, medicina veterinária popular, plantas medicinais

\footnotetext{
1 Universidade Federal do Pará. vivinabm@gmail.com

2 Universidade Estadual do Ceará. claudiamlb@yahoo.com.br

3 Universidade Federal Rural da Amazônia. dora.palha@ufra.edu.br

${ }^{4}$ Secretaria de Desenvolvimento Agrário. roberta_vet@yahoo.com

${ }^{5}$ Universidade Federal do Pará. katiane@ufpa.br

${ }^{6}$ EMBRAPA Amazônia Oriental, Laboratório de Botânica-Herbário. silvanetavares300@pop.com.br

EMBRAPA Amazônia Oriental. osmar@cpatu.embrapa.br
} 


\section{INTRODUCTION}

Folk knowledge and practices have been used by breeders, farmers and veterinary doctors to prevent and treat flock and pet diseases (Mathias 2007). The combination of knowledge, practices, beliefs and methods related to animal health is known as ethnoveterinary, an expression first used in the 1980s by McCorkle (Barboza et al. 2007). In ethnoveterinary treatments, medicinal plants are used (Farooq et al. 2008) as well as minerals (Alawa et al. 2002) and animal products (Barboza et al. 2007). Several factors, including veterinary service costs, difficulty in acquiring synthetic drugs and an increasing demand for organic foods, have expanded interest in research of ethnoveterinary medicine, especially that which relates to phytotherapy (Cárceres et al. 2004).

Ethnoveterinary knowledge is acquired over many years through trial and error; at present, however, due to rapid cultural changes, this information is being lost, highlighting the importance of scientific documentation of ethnoveterinary knowledge (Mathias 2007). There have been many ethnoveterinary reports from around the world regarding the use of plants in therapeutic protocols (Lans and Brown 1998; Alawa et al. 2002; Viegi et al. 2003; Farooq et al. 2008; McGaw and Eloff 2008). In Brazil, particularly in Amazonia, this type of study is seldom undertaken (Barboza et al. 2007).

Amazonia has 25,000-30,000 species of endemic plants (Cunningham 1996) and is inhabited by three types of population that include "quilombolas" (descendants of Afro-Brazilian runaway slaves living in hiding up-country, called quilombos), indigenous ethnic groups and mestizo populations derived from the miscegenation of Europeans, Indians and Black People. The multiple possibilities resulting from biome and local culture interactions grant wealth and complexity to that region regarding understanding of the therapeutic potential of Brazilian flora (Rodrigues 2006).

Brazilian Amazonia is composed of the states of Acre, Amazonas, Amapá, Roraima, Rondônia, Pará and part of Maranhão, Tocantins and Mato Grosso (IBAMA 2007). The island of Marajó is located in the state of Pará, a firth of the Amazon River and the largest fluvial maritime island in the world. The Island of Marajó, like the whole of Amazonia, contains great biological and cultural diversity; thus, this is a very interesting area for phytotherapy research regarding treatment of both humans and animals.

The agricultural practices undertaken in Marajó Island are the most ancient techniques used in the state of Pará. Traditional practices have been in use for approximately 300 years, which until the present time have been primarily applied to Marajó flocks (Barbosa 2005). However, this traditional information is still unregistered; it can eventually be lost, after which time it will be unavailable to future generations.
In addition, traditional practices can give important support to the selection of natural alternatives to veterinary disease treatments and can contribute to the discovery of new drugs. The objective of this work was to register and analyze ethnoveterinary knowledge from the people of Soure and Salvaterra, municipalities on the island of Marajó, Pará, Brazil.

\section{MATERIAL AND METHODS}

\section{Localization of the area}

Located $87 \mathrm{~km}$ from Belém, the metropolis of the state of Pará, the archipelago of Marajó is composed of a set of islands totaling $49,606 \mathrm{~km}^{2}$, divided into 16 municipal districts (Barbosa 2005). Marajó Island is accessed by boat or plane; its main economical activities include agriculture, plant extractivism, breeding, fishing and tourism (Brasil 2007). Based on phytogeography, the island is divided into grasslands (eastern) and rainforest (western). In the grassland area, there are farms of cattle, buffalo and swine breeding; in the rainforest area, activities such as fishing and plant extractivism have been developed (Miranda Neto 2005).

The local vegetation is directly influenced by hydrography, which defines the main regional ecosystems. The population of this area cohabitates with four kinds of ecosystems: "várzea" ("floodplains" - extensive lowland areas bordering the main river and its tributaries), "igapó" (inundated rainforest areas), "terra firme" ("uplands" - non-inundated areas) and natural grasslands (wide open areas of pastures) (Brasil 2007).

The present research was conducted in the eastern region of Marajó Island, in the districts of Salvaterra and Soure. Soure is the main city of the island, comprehending $3,513 \mathrm{~km}^{2}$ of area, with 21,395 inhabitants. Salvaterra has 17,077 inhabitants distributed in an area of $1,044 \mathrm{~km}^{2}$ of area (IBGE 2007). These districts are adjacent and are separated by the Paracauari River, whose crossing takes approximately 10 minutes by motorboat. The two districts contain approximately 37,919 cattle, 40,670 buffalo, 7,981 horses, 978 goats, 1,704 sheep, 5,165 pigs and 8,790 poultry (IBGE 2006). Marajó Island is home to the largest buffalo flocks in Brazil (Barbosa 2005).

The weather is classified as tropical moist, with annual pluviometry defining two seasons, a dry season and a rainy season (Brasil 2007). The mean annual rainfall is $2,500 \mathrm{~mm}$, with high concentration of rain from February to May. The rainy season causes difficulties in accessing some regions of the archipelago, as approximately $2 / 3$ of the island is inundated (Miranda Neto 2005). The mean annual temperature is $26^{\circ} \mathrm{C}$, with high relative humidity ( $>80 \%)$. The thermic amplitude is very low, and the days usually last the same duration of time as the nights (Brasil 2007). 


\section{Data Collection}

Data collection was carried out between November 2008 and March 2009. The survey team was composed of a veterinarian, veterinary assistants, a botanist expert and recruited key people of the municipalities. Individuals with experience in animal husbandry and medicinal use of natural products were selected for the interviews through non-random sampling with a "snowball" method (Albuquerque et al. 2008).

Fifty individuals were interviewed, 19 men and 31 women, with ages ranging from 20 to 90 years old $(52.2 \pm 15.5)$. Semi-structured questionnaires with open- and close-ended questions were used for interviewing. To evaluate the influence of age on ethnoveterinary knowledge, the informants were divided into three age ranges: $20-40$ years old $(n=9), 41-60$ years old $(n=27)$ and over 60 years old $(n=14)$. Of the people interviewed, 23 were from Salvaterra and 27 were from Soure.

Before answering the questionnaires, all informants were informed about the study objectives. After giving their verbal consent, the interviews were undertaken. The questionnaires queried personal information, the main diseases observed and the diagnostic procedures and traditional treatments applied to animals.

Medicinal plant voucher specimens were collected, identified and deposited into the Herbarium of EMBRAPA Amazônia Oriental.

The results obtained were tabulated in Microsoft Excel using quantitative data analysis methods. Use value was calculated using the formula proposed by Phillips and Gentry (1993). To calculate the use-value of one species to an informant $\left(\mathrm{UV}_{\mathrm{is}}\right)$ has used the formula $\mathrm{UV}_{\mathrm{is}}=\Sigma \mathrm{U}_{\mathrm{si}} / \mathrm{n}_{\mathrm{is}}$, where $\mathrm{U}_{\mathrm{si}}$ is the number of uses mentioned by the informant for the species and $\mathrm{n}_{\text {is }}$ the number of interviews with the informant. For this work $n_{\text {is }}$ is always 1 (one), it was done only one interview per informant. Therefore, the value of $U V_{\text {is }}$ is equal to $\mathrm{U}_{\mathrm{si}}$. To calculate the use-value of each species $\left(\mathrm{UV}_{s}\right)$ was used the formula $U V s=\Sigma U_{\mathrm{si}} / \mathrm{n}$, were $\mathrm{UV}_{\mathrm{si}}$ corresponds to the use-value of one species to an informant and $\mathrm{n}$ is the number of informants interviewed. The $\mathrm{n}$ value corresponds to the value of ns reported by Phillips and Gentry (1993), whereas all species could be cited by any informant as described by Vendruscolo and Mentz (2006). Descriptive statistics such as frequency distribution were used to analyze the data, according to Wondimum et al. (2007). The open-ended questions were grouped into classes that expressed similar ideas. Analysis of variance (ANOVA) test was performed, and Student's T-test with $5 \%$ probability was used to evaluate significant differences in the mean of medicinal plants reported by different genders and ages.

\section{RESULTS}

All informants asserted that they usually used medicinal plants to treat their own diseases and those of their animals. According to the questionnaires, knowledge of medicinal plant usage in the studied area was transmitted from one generation to another through oral communication. Among the informants, $68 \%$ asserted that they had learned how to use medicinal plants from their parents, $22 \%$ from grandparents and $10 \%$ from other relatives, neighbors or books. Ninety-six percent of informants pass this knowledge to another people (sons, friends and neighbors).

The comparison between efficacy of medicinal plants and synthetic drugs showed that up to $62 \%$ of informants had more trust in the plants; just $12 \%$ answered that synthetic drugs are more efficient, and $20 \%$ declared that the efficiency depends on the case; in some situations, only the synthetic medicine can treat the problem, while in others, plants can be used with efficacy and safety. Six percent of informants had no opinion about this question.

No significant difference $(\mathrm{p}>0.05)$ was observed between the mean of reported plants for men $(5.9 \pm 2.97)$ and women $(6.42 \pm 2.95)$. However, significant differences $(\mathrm{p}<0.05)$ were observed between the age classes studied and the number of reported plants. In the 41-to-60-year old class, the number of reported plants $(6.74 \pm 3.32)$ was significantly higher than that reported by the 20 -to- 40 -year-old class $(4.11 \pm 2.57)$ and the over 60 -year-old class $(5.93 \pm 1.98)$; however, there was no significant difference between these last two classes.

Fifty-five useful plants were reported to be used for ethnoveterinary treatments (Table 1). From this number, five plants were not able to be collected. The identified plants were distributed along 48 genera and 34 families. The families with large numbers of reported species were Asteraceae, with four species, and Bignoniaceae, Euphorbiaceae, Leguminosae-Caesalpinioideae, all with three species. The families Anacardiaceae, Convovulaceae, Lamiaceae, Meliaceae, Moraceae, Piperaceae and Zingiberaceae were represented by two species each, and the rest of the families had only one reported species. Although the Asteraceae family is the most abundant, species with the highest use value for the studied population belong to the families Bignoniaceeae, Euphorbiaceae and Caesalpiniaceae. With regard to growth habits, $18 \%$ of the species were shrubs, $32 \%$ were trees, $36 \%$ were herbs, $12 \%$ were lianes (a kind of vine) and 2\% were stipes.

Among the 50 identified plants, 342 reports of ethnoveterinary use were collected. The species with highest use-value were "andiroba" (Carapa guianensis Aubl.) $\left(\mathrm{UV}_{\mathrm{s}}=1.62\right)$, "copaíba" (Copaifera martii Hayne) $\left(\mathrm{UV}_{\mathrm{s}}=1\right)$, "cuieira" (Crescentia cujete L.) $\left(\mathrm{UV}_{\mathrm{s}}=0.76\right)$, "jucá" (Caesalpinia ferrea Mart.) $\left(\mathrm{UV}_{\mathrm{s}}=0.76\right)$, "mastruz" (Chenopodium ambrosioides $\mathrm{L}$.) $\left(\mathrm{UV}_{\mathrm{s}}=0.46\right)$, "piáo 
Table 1 - Plants used in ethnoveterinary medicine on Marajó Island, eastern Amazonia, Brazil

\begin{tabular}{|c|c|c|c|c|c|c|}
\hline Scientific name, family, (voucher no.) & Local name & $U_{\text {is }}$ & $U_{\mathrm{s}}$ & Medicinal indication & $\begin{array}{l}\text { Part } \\
\text { used }\end{array}$ & Mode of use \\
\hline Aloe vera (L.) Burm. F., Liliaceae, (184098) & Babosa & 3 & 0.06 & $\begin{array}{l}\text { - Anti-inflammatory and } \\
\text { wound healing }\end{array}$ & L & - Plaster \\
\hline $\begin{array}{l}\text { Alternanthera dentata Scheygrond, Amaranthaceae, } \\
\text { (184105) }\end{array}$ & Meracilina & 2 & 0.04 & $\begin{array}{l}\text { - Diarrhea } \\
\text { - Wound healing }\end{array}$ & $L$ & $\begin{array}{l}\text { - Tea } \\
\text { - Plaster }\end{array}$ \\
\hline Anacardium occidentale L., Anacardiaceae, (184128) & Cajueiro & 4 & 0.08 & $\begin{array}{l}\text { - Diarrhea } \\
\text { - Habronema spp. }\end{array}$ & $\begin{array}{c}B / L \\
B\end{array}$ & $\begin{array}{l}\text { - Tea } \\
\text { - Tea }\end{array}$ \\
\hline Aristolochia sp., Aristolochiaceae, (184136) & $\begin{array}{l}\text { Cipó de } \\
\text { cobra }\end{array}$ & 3 & 0.06 & - Diarrhea, colic and vomit & $\mathrm{R}$ & - Tea made with roots \\
\hline $\begin{array}{l}\text { Arrabideae chica (Humb. \& Bonpl.) B. Verl., } \\
\text { Bignoniaceae, (184139) }\end{array}$ & Pariri & 2 & 0.04 & - Anemia & L & - Tea \\
\hline Azadirachta indica A. Juss., Meliaceae, (184126) & $\mathrm{Nin}$ & 2 & 0.04 & - Fly repellant & $\mathrm{L}$ & - Juice \\
\hline Bixa orellana L., Bixaceae, (184108) & Urucum & 9 & 0.18 & $\begin{array}{c}\text { - Fowlpox } \\
\text { - Wound healing } \\
\text {-Infectious coryza poultry }\end{array}$ & $\begin{array}{l}S \\
S \\
S\end{array}$ & $\begin{array}{l}\text { - Seeds ground } \\
\text { - Infusion in water } \\
\text { - Infusion in water }\end{array}$ \\
\hline $\begin{array}{l}\text { Bryophyllum calycinum Salisb., Crassulaceae, } \\
\text { (184103) }\end{array}$ & Pirarucu & 3 & 0.06 & $\begin{array}{l}\text { - Wound healing } \\
\text { - Diarrhea } \\
\text { - Snake bite }\end{array}$ & $\begin{array}{l}L \\
L \\
L\end{array}$ & $\begin{array}{l}\text { - Juice } \\
\text { - Tea } \\
\text { - Juice }\end{array}$ \\
\hline $\begin{array}{l}\text { Caesalpinia ferrea Mart., Leguminosae-Caesalp., } \\
(184100)\end{array}$ & Jucá & 38 & 0.76 & $\begin{array}{l}\text { - Wound healing } \\
\text { - Cough }\end{array}$ & $\begin{array}{l}P \\
P\end{array}$ & $\begin{array}{l}\text { - Infusion in alcohol } \\
\text { - Infusion in water or Syrup }\end{array}$ \\
\hline Carapa guianensis Aubl., Meliaceae, (184124) & Andiroba & 81 & 1.62 & $\begin{array}{c}\text { - Wound healing } \\
\text { - Anti-inflammatory } \\
\text { - Skin problems } \\
\text { - Cough } \\
\text { - Fly repellant } \\
\text { - Tick infestation } \\
\text { - Infectious coryza poultry } \\
\text { - Myiasis } \\
\text { - Purgative } \\
\text { - Habronema spp. }\end{array}$ & $\begin{array}{l}\text { S } \\
S \\
S \\
S \\
S \\
S \\
S \\
S \\
S \\
S\end{array}$ & $\begin{array}{l}\text { - Ointment with oil and salt } \\
\text { - Oil pure for massage } \\
\text { - Oil pure } \\
\text { - Oil with juice of C. limon } \\
\text { - Ointment with salt } \\
\text { - Oil with charcoal } \\
\text { - Oil from seeds in water } \\
\text { - Oil from seeds } \\
\text { - Oil adding water } \\
\text {-Oil applied topically }\end{array}$ \\
\hline Carica papaya L., Caricaceae, (184130) & Mamão & 2 & 0.04 & - Anthelmintic & S & - Seed powder in water \\
\hline $\begin{array}{l}\text { Chenopodium ambrosioides L., Chenopodiaceae, } \\
\text { (184135) }\end{array}$ & Mastruz & 23 & 0.46 & $\begin{array}{l}\text { - Anthelmintic } \\
\text { - Cough } \\
\text { - Wound healing } \\
\text { - Anti-inflammatory } \\
\text { - Diarrhea }\end{array}$ & $\begin{array}{l}L \\
L \\
L \\
L \\
L\end{array}$ & $\begin{array}{l}\text { - Juice or tea. Juice with milk } \\
\text { - Juice with milk } \\
\text { - Plaster } \\
\text { - Plaster } \\
\text { - Juice }\end{array}$ \\
\hline Citrus limon (L.) Burm. F., Rutaceae, (184140) & Limão & 2 & 0.04 & - Infectious coryza poultry & $\mathrm{Fr}$ & - Juice \\
\hline Cocos nucifera L., Arecaceae, (184129) & Coco & 6 & 0.12 & $\begin{array}{c}\text { - Diarrhea } \\
\text { - Anthelmintic } \\
\text { - Skin problems }\end{array}$ & $\begin{array}{c}\mathrm{Fr} / \mathrm{R} \\
\mathrm{Fr} \\
\mathrm{Fr}\end{array}$ & $\begin{array}{c}\text { - Tea } \\
\text { - Milk from mature coconut } \\
\text { - Oil from mature coconut }\end{array}$ \\
\hline $\begin{array}{l}\text { Copaifera martii Hayne., Leguminosae-Caesalp., } \\
\text { (184117) }\end{array}$ & Copaíba & 50 & 1 & $\begin{array}{c}\text { - Wound healing } \\
\text { - Anti-inflammatory } \\
\text { - Infectious coryza poultry } \\
\text { - Diarrhea } \\
\text { - Myiasis } \\
\text { - Habronema spp. } \\
\text { - Anthelmintic } \\
\text { - Cough }\end{array}$ & $\begin{array}{l}0 \\
0 \\
0 \\
B \\
0 \\
0 \\
B \\
0\end{array}$ & $\begin{array}{c}\text { - Oil, pure or with ointment } \\
\text { - Oil with of } C \text {. guianensis oil } \\
\text { - Drops of oil in water } \\
\text { - Tea } \\
\text { - Oil with salt } \\
\text { - Oil with C. guianensis oil } \\
\text { - Tea } \\
\text { - One tablespoon of oil orally }\end{array}$ \\
\hline Costus spiralis (Jacq.) Roscoe., Costaceae, (184133) & Canarana & 1 & 0.02 & - Kidney problems & L & - Tea \\
\hline Crescentia cujete L., Bignoniaceae, (184099) & Cuieira & 38 & 0.76 & $\begin{array}{l}\text { - Skin problems, wound } \\
\text { healing and fly repellant }\end{array}$ & $\mathrm{Fr}$ & - Green flesh \\
\hline Cymbopogon citratus (DC.) Stapf., Poaceae, (184119) & $\begin{array}{l}\text { Capim } \\
\text { marinho }\end{array}$ & 4 & 0.08 & $\begin{array}{l}\text { - Diarrhea } \\
\text { - Tick infestation }\end{array}$ & $L$ & $\begin{array}{l}\text { - Tea } \\
\text { - Infused with alcohol }\end{array}$ \\
\hline
\end{tabular}




\begin{tabular}{|c|c|c|c|c|c|c|}
\hline Scientific name, family, (voucher no.) & Local name & $\mathrm{UV}_{\text {is }}$ & $\mathrm{UV}_{\mathrm{s}}$ & Medicinal indication & $\begin{array}{l}\text { Part } \\
\text { used }\end{array}$ & Mode of use \\
\hline $\begin{array}{l}\text { Dalbergia monetaria L. f., Leguminosae-Pap., } \\
\text { (184142) }\end{array}$ & Verônica & 3 & 0.06 & $\begin{array}{c}\text { - Diarrhea } \\
\text { - Anemia } \\
\text { - Wound healing }\end{array}$ & $\begin{array}{l}B \\
B \\
B\end{array}$ & $\begin{array}{c}\text { - Tea } \\
\text { - Tea } \\
\text { - Ointment with "oleo-de-bicho" }\end{array}$ \\
\hline Dorstenia asaroides Hook., Moraceae, (184110) & Apii & 2 & 0.04 & - Cough & $\mathrm{R}$ & - Tea \\
\hline Eleutherine plicata herb., Iridaceae, (184116) & Marupazinho & 4 & 0.08 & - Diarrhea and colic & $\mathrm{R}$ & - Tea \\
\hline Eupatorium triplinerve Vahl., Asteraceae, (184131) & $\begin{array}{l}\text { Japana } \\
\text { branca }\end{array}$ & 2 & 0.04 & - Cough & L & - Juice \\
\hline Ficus maxima Mill., Moraceae, (184141) & Caxinguba & 2 & 0.04 & - Anthelmintic & B & - Tea \\
\hline Guasuma tormentosa Kunth., Sterculiaceae, (184095) & Envireira & 1 & 0.02 & - Diarrhea & B & - Tea \\
\hline Heliotropium indicum L., Boraginaceae, (184093) & Fedegoso & 6 & 0.12 & $\begin{array}{l}\text { - Anti-inflammatory } \\
\text { - Wound healing }\end{array}$ & $\begin{array}{l}L \\
L\end{array}$ & $\begin{array}{l}\text { - Plaster with C. guianensis oil. } \\
\text { - Crushed with C. guianensis oil }\end{array}$ \\
\hline $\begin{array}{l}\text { Ipomoea asarifolia (Desr.)Roem. \& Schult., } \\
\text { Convovulaceae, (184112) }\end{array}$ & Salsa & 7 & 0.14 & $\begin{array}{l}\text { - Fly repellant } \\
\text { - Skin problems }\end{array}$ & $\begin{array}{l}L \\
L\end{array}$ & $\begin{array}{l}\text { - Crushed leaves } \\
\text { - Tea or infusion in water or } \\
\text { alcohol. }\end{array}$ \\
\hline Ipomoea carnea Jacq., Convovulaceae, (184122) & $\begin{array}{l}\text { Algodão } \\
\text { bravo }\end{array}$ & 4 & 0.08 & $\begin{array}{l}\text { - Tick infestation } \\
\text { - Fly repellant }\end{array}$ & $\begin{array}{l}\mathrm{L} \\
\mathrm{L}\end{array}$ & $\begin{array}{l}\text { - Crushed leaves } \\
\text { - Infusion in water }\end{array}$ \\
\hline Jatropha curcas L., Euphorbiaceae, (184097) & Pião branco & 20 & 0.4 & $\begin{array}{l}\text { - Tick infestation } \\
\text { - Anthelmintic } \\
\text { - Wound healing }\end{array}$ & $\begin{array}{l}S \\
S \\
L\end{array}$ & $\begin{array}{l}\text { - Seeds burnt to create a smoke } \\
\text { - Crushed in milk or food } \\
\text { - Exudate from leaves }\end{array}$ \\
\hline $\begin{array}{l}\text { Mansoa alliaceae (Lam.) A.H. Gentry., Bignoniaceae, } \\
\text { (184120) }\end{array}$ & Cipó d’alho & 4 & 0.08 & - Fly repellant & L & - Juice \\
\hline Mentha crispa L., Lamiaceae, (184107) & Hortelãzinho & 3 & 0.06 & - Colic & L & - Tea \\
\hline Mikania lindleyana DC., Asteraceae, (184102) & Sucuriju & 1 & 0.02 & - Diarrhea & L & - Tea \\
\hline Momordica charantia L., Cucurbitaceae, (184111) & São-caetano & 19 & 0.38 & $\begin{array}{l}\text { - Skin problems } \\
\text { - Strangles } \\
\text { - Anthelmintic } \\
\text { - Fly repellant } \\
\text { - Habronema spp. }\end{array}$ & $\begin{array}{l}L \\
L \\
L \\
L \\
L\end{array}$ & $\begin{array}{l}\text { - Tea or juice } \\
\text { - Juice with the fat of } M \text {. niger } \\
\text { - Juice } \\
\text { - Juice } \\
\text { - Juice }\end{array}$ \\
\hline Ouratea acuminata (DC.) Engl., Ochnaceae, (184092) & Barbatimão & 7 & 0.14 & $\begin{array}{l}\text { - Wound healing } \\
\text { - Diarrhea and colic } \\
\text { - Habronema spp. } \\
\text { - Anti-inflammatory }\end{array}$ & $\begin{array}{l}B \\
B \\
B \\
B\end{array}$ & $\begin{array}{l}\text { - Burned shell powder } \\
\text { - Tea } \\
\text { - Burned shell powder } \\
\text { - Tea }\end{array}$ \\
\hline Persea americana Mill., Lauraceae, (184121) & Abacate & 1 & 0.02 & - Snake bite & S & - Infusion in alcohol \\
\hline Petiveria alliacea L., Phytolaccaceae, (184118) & Mucura-caá & 1 & 0.02 & - Fly repellant & L & - Juice mixed with salt \\
\hline Phyllanthus niruri L., Euphorbiaceae, (184134) & $\begin{array}{l}\text { Quebra } \\
\text { pedra }\end{array}$ & 1 & 0.02 & - Kidney problems & WP & - Tea \\
\hline Piper callosum Ruiz \& Pav., Piperaceae, (184137) & $\begin{array}{c}\text { Elixir } \\
\text { paregórico }\end{array}$ & 1 & 0.02 & - Diarrhea & $\mathrm{L}$ & - Tea \\
\hline Piper sp., Piperaceae, (184090) & $\begin{array}{l}\text { Jambu do } \\
\text { mato }\end{array}$ & 2 & 0.04 & $\begin{array}{l}\text {-Stimulant to improve the } \\
\text { smell of dogs }\end{array}$ & $\mathrm{R}$ & - Crushed root or tea \\
\hline Plectranthus barbatus Andrews, Lamiaceae, (184115) & Anador & 3 & 0.06 & - Diarrhea and colic & $\mathrm{L}$ & - Tea \\
\hline $\begin{array}{l}\text { Pluchea suaveolens (Vell). Kuntze, Asteraceae, } \\
\text { (104096) }\end{array}$ & Lógena & 1 & 0.02 & - Antihelminthic & L & - Tea \\
\hline Portulaca pilosa L., Portulacaceae, (184104) & $\begin{array}{l}\text { Amor } \\
\text { crescido }\end{array}$ & 10 & 0.2 & $\begin{array}{l}\text { - Wound healing } \\
\text { - Habronema spp. } \\
\text { - Colic }\end{array}$ & $\begin{array}{l}L \\
L \\
L\end{array}$ & $\begin{array}{l}\text { - Poultice } \\
\text { - Macerated leaves } \\
\text { - Tea }\end{array}$ \\
\hline Psidium guajava L., Myrtaceae, (184127) & Goiabeira & 9 & 0.18 & $\begin{array}{c}\text { - Diarrhea } \\
\text { - Wound healing }\end{array}$ & $\begin{array}{l}L \\
B\end{array}$ & $\begin{array}{l}\text { - Tea } \\
\text { - Tea }\end{array}$ \\
\hline Quassia amara L., Simaroubaceae, (184109) & Quina & 1 & 0.02 & - Skin problems & $\mathrm{L}$ & - Infusion with water \\
\hline
\end{tabular}




\begin{tabular}{|c|c|c|c|c|c|c|}
\hline Scientific name, family, (voucher no.) & Local name & $\mathrm{UV}_{\text {is }}$ & $\mathrm{UV}_{\mathrm{s}}$ & Medicinal indication & $\begin{array}{l}\text { Part } \\
\text { used }\end{array}$ & Mode of use \\
\hline Ricinus communis L., Euphorbiaceae, (184114) & Mamona & 4 & 0.08 & $\begin{array}{l}\text { - Tick infestation and fly } \\
\text { repellant } \\
\text { - Antihelminthic }\end{array}$ & $\begin{array}{l}S \\
S\end{array}$ & $\begin{array}{l}\text { - Seeds burnt to create a smoke } \\
\text { - Oil pure in water }\end{array}$ \\
\hline Rolandra argentea Rottb., Asteraceae, (184101) & Pai Joaquim & 1 & 0.02 & - Kidney problems & $\mathrm{R}$ & - Tea \\
\hline Scoparia dulcis L., Scrophulariaceae, (184091) & Vassourinha & 1 & 0.02 & - Evil eye & WP & $\begin{array}{c}\text { - Passing the animal to remove } \\
\text { evil eye }\end{array}$ \\
\hline $\begin{array}{l}\text { Senna obtusifolia (L.) H.S. Irwin \& Barneby, } \\
\text { Leguminosae-Caesalp., (184113) }\end{array}$ & Mata pasto & 1 & 0.02 & - Skin problems & $\mathrm{L}$ & - Macerated \\
\hline Spondias mombin L., Anacardiaceae, (184123) & Taperebá & 3 & 0.06 & $\begin{array}{l}\text { - Habronema spp. and } \\
\text { wound healing }\end{array}$ & B & - Tea \\
\hline Zingiber officinale Roscoe, Zingiberaceae, (184132) & Gengibre & 1 & 0.02 & - Cough & $\mathrm{R}$ & - Macerated with sugar \\
\hline Ziziphus joazeiro Mart., Rhamnaceae, (184138) & Juá & 2 & 0.04 & - Fly repellant & $\mathrm{L}$ & - Juice \\
\hline
\end{tabular}

L-leaves, B- bark, Fr- fruit, S-seed, R-roots, P- pods, 0-oil, WP- whole plant.

branco" (Jatropha curcas L.) $\left(\mathrm{UV}_{\mathrm{s}}=0.4\right)$ and "São-Caetano" (Momordica charantia $\mathrm{L}$.) $\left(\mathrm{UV}_{\mathrm{s}}=0.38\right)$. These species also had the highest numbers of medicinal indications. C. guianensis was reported to treat 10 different diseases. Table 1 describes the reported plants and their respective indications, use-value, methods and parts used for preparing the ethnoveterinary medicines. The plants reported by the informants were indicated for every species of domestic animal present in the studied area, including dogs, cats, buffalo, cattle, horses, pigs and poultry.

The plant parts that were more frequently used to prepare ethnoveterinary medicines were the leaves (56\%), bark (18\%), roots $(14 \%)$, seeds $(14 \%)$ and fruit $(8 \%)$. The use of whole plants, oil and pods were rarely reported. Regarding the methods of use, the most utilized method was tea $(56 \%)$, followed by juice $(20 \%)$, powder $(14 \%)$, maceration $(10 \%)$ and water infusion (10\%); other preparation methods were less commonly reported. Oral administration was reported as the main method of administration, using tea, juice and fruit. Topical administration was most frequently used for treating skin problems, as fly repellent and for tick infestation, wound healing and anti-inflammatory treatments. In these cases, the main methods used are baths, plasters and massages.

Most preparations (90.9\%) employed only a single plant, while in $9.1 \%$ of cases, different medicinal plants were used to prepare the herbal medicine. Doses were not standardized, and treatment duration was the time period until symptoms diminished.

The 50 identified plants were indicated for 21 different medicinal purposes (Table 2). The largest number of species was reported for treatment of diarrhea and wound healing (16 species), followed by use as a fly repellent (10 species), anthelmintic (9 species) and treatment of skin problems (8 species). Other indications were related to a minor number of species.
Table 2 - Absolute and relative frequencies of medicinal indications related to the plants mentioned in the ethnoveterinary medicine practiced on Marajó Island, Eastern Amazon, Brazil.

\begin{tabular}{lcc}
\hline Medical indication & $\begin{array}{c}\text { Absolute } \\
\text { frequency }\end{array}$ & $\begin{array}{c}\text { Relative } \\
\text { frequency (\%) }\end{array}$ \\
\hline Wound healing & 16 & 32 \\
\hline Diarrhea & 16 & 32 \\
\hline Fly repellant & 10 & 20 \\
\hline Anthelmintic & 9 & 18 \\
\hline Skin problems & 8 & 16 \\
\hline Anti-inflammatory & 7 & 14 \\
\hline Habronema spp. & 7 & 14 \\
\hline Cough & 7 & 14 \\
\hline Colic & 6 & 12 \\
\hline Tick infestation & 5 & 10 \\
\hline Infectious coryza poultry & 4 & 8 \\
\hline Kidney problems & 3 & 6 \\
\hline Anemia & 2 & 4 \\
\hline Myiasis & 1 & 2 \\
\hline Snake bite & 1 & 2 \\
\hline Evil eye & 1 & 2 \\
\hline Fowlpox & 1 & 2 \\
\hline Strangles & 1 & 2 \\
\hline Stimulant to improve the smell of dogs & 1 & 2 \\
\hline Purgative & 1 & 2 \\
\hline Vomit & 1 & 2 \\
\hline & 1 & 2 \\
\hline
\end{tabular}


Beyond plants, $76 \%$ of informants reported products of animal origin as being useful for ethnoveterinary treatments. In the studied population, some wild and domestic animals have therapeutic uses, such as the lard of "jacaré-açu" (Melanosuchus niger), "sucuriju" (Eunectes murinus), "galinha" (Gallus Gallus) and invertebrate animals. The lard of M. niger was reported by $42 \%$ of informants for the treatment of horse respiratory diseases or anti-inflammatory, wound healing and purgative treatments. The "óleo-de-bicho," an oil obtained from beetle larvae (Rhynchophorus palmarum, Coleoptera) found in "tucumä" seeds (Astrocaryum aculeatum), a common palm tree in the region, was also reported as being medicinal by $58 \%$ of informants. The main applications of this oil are wound healing and anti-inflammatory treatments.

The use of salt, sulfur, vegetal charcoal, alcohol, sugar, bee honey and buffalo milk were reported for preparing ethnoveterinary herbal medicines; however, water was the main vehicle mentioned for preparative use.

\section{DISCUSSION}

This study is the first scientific communication regarding the ethnoveterinary practices employed by the inhabitants of Marajó Island. The results showed that the studied population retains ethnoveterinary knowledge that has been orally transmitted from one generation to the next, this kind of knowledge transmission also has been reported in other regions of Brazil (Barboza et al. 2007) as well as Nigeria (Alawa et al. 2002), Pakistan (Farooq et al. 2008) and Ethiopia (Giday et al. 2009).

It has been observed that traditional uses of plants for the treatment of human diseases are frequently also used in veterinary treatments (Alawa et al. 2002; Giday et al. 2009). The studied population demonstrated more trust in ethnoveterinary medicine than in veterinary allopathic medicine due to easy acquisition and effectiveness of some native plants. The low purchasing power and lack of veterinary services are factors that contribute to people choosing ethnoveterinary medicine. In addition to these factors, the tradition in animal husbandry on the Marajó Island is about 300 years old, fact that may also explain the preference and trust of the population in use of medicinal plants.

In this study the knowledge regarding the treatment of animal diseases did not show any difference between genders. In other studies, however, it was observed that men had more knowledge of plant usage because they are naturally selected during childhood to be apprentices of ethnoveterinary practices (Giday et al. 2009). In addition, in some regions, labor division makes women responsible for housekeeping only, while men take care of the animals (Farooq et al. 2008). Depending on labor division, men might be better able to manage farm animals, or women might have more experience with pets or have different experiences with diseases such as mastitis or newborn illnesses (Mathias 2007).

The Asteraceae family had the largest number of reported plants, most likely due to its large diversity of species in the studied area. This family was also more commonly reported as being medicinal in ethnobotanical surveys conducted in Amazonas (Rodrigues 2006), Roraima (Pinto and Maduro 2003), Bolivian Amazonia (Vandebroek et al. 2004) and other countries (Ketzis and Brown 2002; Giday et al. 2009).

The use value is a quantitative method that demonstrates the relative importance of species known locally. This technique can be used to select species for cultivation in gardens or construction of medical work of scientific validation (Vendruscolo and Mentz 2006). C. guianensis and C. martii were the species with highest use-value, probably because they originated in Amazonia. These plants are largely known to North Brazil's inhabitants and other countries of the Amazonia region (Rodrigues 2006). The oil from $C$. guianensis seeds is used by Brazilian and Venezuelan Amazonia inhabitants to treat inflammation, flu and skin afflictions (Delascio 1985).

Other species, such as J. curcas, C. ferrea, C. cujete, $C$. ambrosioides and $M$. charantia, despite being exotic in the studied area, had high reporting use-values. In Brazil, the cultural mixing of native, African and European people introduced several species of other continents into popular medicine (Brandáo et al. 2008). This fact was also observed in Amazonia (Di Stasi and Hiruma-Lima 2002), explaining the heavy use of exotic species demonstrated in the present study. Substitution of native species for exotic ones emphasizes the importance of research into the recovery of information about extinct plants and their uses, which could be lost forever (Brandão et al. 2008).

Some reported plants were also described in other surveys to treat similar diseases. C. nucifera (Hunssain et al. 2008), C. papaya and C. ambrosioides (Lans et al. 2000; Ketzis and Brown 2002) are natural anthelmintic; Citrus limon (L.) Burm. F. and $M$. charantia are used to treat respiratory diseases in poultry (Lans and Brown 1998), Azadirachta indica A. Juss is used as a repellent (Farooq et al. 2008), Psidium guajava L. and Anacardium occidentale L. are used for diarrhea (Lans et al. 2000), and C. cujete is used for skin afflictions (Lans et al. 2000). Medicinal plants that are reported by different informants and communities but with the same therapeutic indications represent traces of true efficacy (Giday et al. 2009).

The present study showed that the most popular indications for medicinal plant usage were the treatment of diarrhea, skin lesions, worms, wound healing and other minor illnesses. Similar results were obtained in different parts of the world (Alawa et al. 2002; Tabuti et al. 2003). Ethnoveterinary medicine is an effective, low-cost alternative for treating minor 
illnesses. Nevertheless, in some situations, such as epidemic infectious and generalized bacterial diseases, conventional medicines and synthetic drugs are the best choices (Mathias 2007). Gradé et al. (2009), McGaw and Eloff (2008) and Viegi et al. (2003) also reported the use of medicinal plants in treating anemia, snake bite, fowlpox, influenza, infectious coryza poultry and vomit, medical indications reported less frequently in this study (Table 2). The use of plants as protectors against evil eye was also mentioned in ethnoveterinary surveys (Ali 1999; Sori et al. 2004).

Most ethnoveterinary preparations in the present study use just one medicinal plant. The use of two or more plants simultaneously reflects the idea of synergism, when an association of plants might result in increased therapeutic efficacy (Giday et al. 2007), as may be the case for the mixing of bark tea of Anacardium occidentale L. and the leaves of Psidium guajava $\mathrm{L}$., indicated to treat diarrhea.

The informants did not report standardized dosing or treatment duration. This was also observed in other ethnoveterinary surveys (Tabuti et al. 2003; Farooq et al. 2008; Hussain et al. 2008; Giday et al. 2009). The absence of precision is common in ethnoveterinary medicine (McCorkle 1986; Mathias 2001) and is a reason to raise skepticism for veterinarians, who generally utilize veterinary allopathy (Farooq et al. 2008).

The studied population reported using products of animal origin. This practice is common in traditional medicine of several countries and is known as zootherapy (Alves and Rosa 2005). In the Amazonian region, there are reports of the use products of animal origin for the treatment of human sicknesses (Luz 2001; Pinto and Maduro 2003; Rodrigues 2006; Ribeiro et al. 2007), although there are no scientific accounts of the use of these products in veterinary medicine. The "óleo-de-bicho" is used in an Amazonian coastal community of Marudá- PA to combat human rheumatism (Coelho-Ferreira 2009). The lard of M. niger and E. murinus are used in popular medicine in the state of Amazonas (Rodrigues 2006) and Roraima (Pinto and Maduro 2003) to treat inflammatory processes; these same therapeutic indications were reported in the present study.

This study contributed to the construction of an inventory of Marajó Island's ethnoveterinary plants, which could be the basis for future scientific validation studies. Scientific evidence of pharmacological properties of these plants support the development of new low-cost drugs that are harmless to the environment and are safe and effective for the treatment of animals.

\section{ACKNOWLEDGEMENT}

The authors would like to thank $\mathrm{CNPq}$ for financial support. Dr. Bevilaqua is a CNPq researcher.

\section{LITERATURE CITED}

Alawa, J.P.; Jokthan, G.E.; Akut, K, 2002. Ethnoveterinary medical practice for ruminants in the subhumid zone of northern Nigéria. Preventive Veterinary Medicine, 54: 79-90.

Albuquerque, U.P.; Lucena, R.F.P.; Cunha, L.V.F.C. 2008. Métodose técnicas na pesquisa etnobotânica. second ed. Comunigraf, Recife. 324 pp. (In Portuguese)

Ali, Z.A. 1999. Folk veterinary medicine in Moradabad District (Uttar Pradesh), Índia. Fitoterapia, 70: 340-347.

Alves, R.R.N.; Rosa, I. 2005. Why study the use of animal products in traditional medicines? Journal of Ethnobiology and Ethnomedicine, 1:1-5.

Barbosa, N.G.S. 2005. Bubalinocultura no Estado do Pará. Revista Brasileira de Reprodução Animal, 29: 34-38. (In Portuguese, with abstract in English)

Barboza, R.R.D.; Souto, W.M.S.; Mourão, J.S. 2007. The use of zootherapeutics in folk veterinary medicine in the district of Cubati, Paraíba State, Brazil. Journal of Ethnobiology and Ethnomedicine, 3:1-14.

Brandão, G.L.; Zanetti, N.N.S.; Oliveira, P.; Grael, C.F.F.; Santos, A.C.P.; Monte-Mór, R.L.M. 2008. Brazilian medicinal plants described by $19^{\text {th }}$ century European naturalist and the official pharmacopoeia. Journal of Ethnopharmacology, 120: 41-148.

Brasil, 2007. Plano de desenvolvimento territorial sustentável do arquipélago do Marajó. (http://www.sudam.gov.br/ Adagenor/PRDA/Plano-Marajo/07_0035_FL.pdf). Acesso em 21/09/2009.

Cárceres A.; Diéguez R.; Loarca A.; Chang D.E. 2004. La etnoveterinária como um instrumento para la atención integral de la produción pecuária, p: 6-8. In: Anais do XIII Congresso Italo-Latino Americano do Etnomedicina. Facolta'di Farmacia, Roma.

Coelho-Ferreira, M. 2009. Medicinal knowledge and plant utilization in Amazonian coastal community of Marudá, Pará State (Brasil). Journal of Ethnopharmacology, 126: 159-175.

Cunningham, A.B. 1996. Professional ethics and ethnobotanical research, p. 19-51. In: Alexiades, M.N (Ed.). Selected Guidelines for Ethnobotanical Research: A field manual.The New York Botanical Garden Press, New York. 306 pp.

Delascio, F. 1985. Algunas plantas usadas en la medicina empírica venezolana. Dirección de Investigaciones Biológicas. División de Vegetación. Jardín Botánico - Inparques, Caracas. 186 pp. (In spanish)

Di Stasi L.C.; Hiruma-Lima, C.A. 2002. Plantas medicinais na Amazônia e na Mata Atlântica. Editora UNESP, São Paulo. 604 pp. (In Portuguese) 
Farooq, Z.; Iqbal, Z.; Mushtaq, S.; Muhammad, G.; Zafar, M.; Iqbal Arshad, M. 2008. Ethnoveterinary practices for the treatment of parasitic diseases in livestock in Cholistan desert (Pakistan). Journal of Ethnopharmacology, 118: 213-219.

Giday, M.; Teklehaymanot, T.; Animut, A.; Mekonnen, Y. 2007. Medicinal plants of the Shinasha, Agew-awi and Amhara peoples in northwest Ethiopia. Journal of Ethnopharmacology, 110: 516-525.

Giday, M.; Asfaw, Z.; Woldu, Z. 2009. Medicinal plants of the Meinit ethnic group of Ethiopia: An ethnobotanical study. Journal of Ethnopharmacology 124: 513-521.

Hussain A.; Khan, M.N.; Iqbal, Z.; Sajid, M.S. 2008. An account of the botanical anthelmintics used in traditional veterinary practices in Sahiwal district of Punjab, Pakistan. Journal of Ethnopharmacology, 119: 185-190.

Gradé, J.T.; Tabuti, J.R.S.; Van Damme, P. 2009. Ethnoveterinary knowledge in pastoral Karamoja, Uganda. Journal of Ethnopharmacology 122: 273-293.

IBAMA, 2009. Ecossistemas Brasileiros. (http://www.ibama.gov.br/ ecossistemas/amazonia.htm.). Acesso em 20/09/2009.

IBGE, 2006. Censo Agropecuário. Espécie de efetivo - Número de cabeças (http://www.ibge.gov.br/cidadesat/topwindow.htm.). Acesso em 13/05/2009.

IBGE, 2007. Censo Demográfico do Brasil. Contagem da população por faixa etária. (http://www.ibge.gov.br/cidadesat/topwindow. htm.). Acesso em 16/04/2009.

Ketzis, J.K.; Brown, D.L. 2002. Medicinal plants used to treat livestock in Honduras. Journal of Herbs, Spices and Medicinal Plants, 10: 55-64.

Lans, C.; Brown, G. 1998. Ethnoveterinary medicines used for ruminants in Trinidad and Tobago. Preventive Veterinary Medicine, 35: 149-163.

Lans, C.; Haper, T.; Georges, K.; Bridgewater, E. 2000. Medical plants used for dogs in Trinidad and Tobago. Preventive Veterinary Medicine, 45: 201-220.

Luz, F.J.F. 2001. Plantas medicinais de uso popular em Boa Vista, Roraima, Brasil. Horticultura Brasileira, 19: 88-89. (In Portuguese, with abstract in English).

Mathias, E. 2007. Ethnoveterinary medicine in the era of evidencebased medicine: Mumbo-jumbo or a valuable resource? The Veterinary Journal, 173: 241-242.

McCorkle, C.M. 1986. An introduction to ethnoveterinary research and development. Journal of Ethnobiology, 6: 129-149.

McGraw, L.J.; Eloff, J.N. 2008. Ethnoveterinary use of southern African plants and scientific evaluation of their medicinal properties. Journal of Ethnopharmacology, 119: 559-74.
Miranda Neto, M.J. 2005. Marajó: Desafio da Amazônia-aspectos da reaçâo a modelos exógenos de desenvolvimento. EDUFPA, Belém. $218 \mathrm{pp}$. (In portuguese).

Phillips, O.; Gentry, E. 1993. The useful plants of Tambopata, Peru: I. Statistical hypotheses tests with a new quantitative technique. Economic Botany, 47: 15-32.

Pinto, A.A.C.; Maduro, C.B. 2003. Produtos e subprodutos da medicina popular comercializados na cidade de Boa Vista, Roraima. Acta Amazonica, 33: 281-290. (In Portuguese, with abstract in English)

Ribeiro, A.S.S.; Palha, M.D.C.; Tourinho, M.M.; Whiteman, C.W.; Silva, A.S.L. 2007. Utilizaçâo dos recursos naturais por comunidades humanas do Parque Ecoturístico do Guamá, Belém, Pará. Acta Amazonica, 37: 235-240. (In Portuguese, with abstract in English)

Rodrigues, E. 2006. Plants and animals utilized as medicines in the Jaú National Park (JNP), Brazilian Amazon. Phytotherapy Research, 20: 378-391.

Sori, T.; Bekana, M.; Adugna, G.; Kelbessa, E. 2004. Medicinal plants in the practices of Borana pastoralists, Southern Ethiopia. International Journal Applied Research Veterinary Medicine. 2: 220-225.

Tabuti, J.R.S.; Dhillion, S.S.; Lye, K.A. 2003. Ethnoveterinary medicines for cattle (Bos indicus) in Bulamogi county, Uganda: plant species and mode of use. Journal of Ethnopharmacology, 88: 279-286.

Vandebroek, I.; Damme, P.V.; Puyveld, L.V.; Arrazola, S., Kimpe, N. 2004. A comparison of traditional healer's medicinal plant knowledge in the Bolivian Andes and Amazon. Social Science and Medicine, 59: 837-849.

Vendruscolo, G.S.; Mentz, L.A. 2006. Estudo da concordância das citaçôes de uso e importância das espécies e famílias utilizadas como medicinais pela comunidade do bairro ponta Grossa, Porto Alegre, RS, Brasil. Acta Botanica Brasilica, 20: 382-382. (In Portuguese, with abstract in English).

Viegi, L.; Pieroni, A.; Guarrera, P. M.; Vangelisti, R. 2003. A review of plants used in folk veterinary medicine in Italy as basis for a databank. Journal of Ethnopharmacology, 89: 221-244.

Wondimum, T.; Asfaw, Z.; Kelbessa, E. 2007. Ethnobotanical study of medicinal plants around "Dheeraa" town, Arsi Zone, Ethiopia. Journal of Ethnopharmacology, 112: 152-161.

Recebido em 10/03/2010

Aceito em 03/07/2010 
